\title{
IS CENTRAL EUROPE SAFE FROM ENVIRONMENTAL LEAD INTOXICATIONS? A CASE SERIES
}

\author{
Daniela Pelclová1, Jana Št’astná2, Štěpánka Vlčková1, Kamil Vlček', Michal Urban¹, Andrea Laštovková1, Zdeněk \\ Doležel ${ }^{2}$ \\ ${ }^{1}$ Department of Occupational Medicine, First Medical Faculty, Charles University in Prague and General University Hospital in Prague, Czech Republic \\ ${ }^{2}$ Department of Paediatrics, Faculty of Medicine, Masaryk University and Faculty Hospital Brno, Czech Republic
}

\section{SUMMARY}

Preventive measures in Central Europe were successful in suppressing both occupational and environmental lead exposure so that they did not constitute a severe public health problem. However, rare lead intoxications still appear. We report on lead intoxication in four family members where the source was removed lead ceiling paint. The symptoms of the lead intoxication started several weeks after removal and the inhalational exposure to the minimum dust residues lasted for more than three months before the poisoning was diagnosed. Father developed anaemia and saturnine colics. He and his two daughters received antidotal treatment which had to be repeated in the children. Finally, all recovered completely. Lead intoxication may be easily overlooked due to the unspecific symptoms. It is necessary to think of this rare poisoning which may be caused by old paints, historical ceramics and lead shots, in addition to commercial products imported from abroad.

Key words: lead, paints, intoxication, prevention, diagnosis, treatment

Address for correspondence: D. Pelclová, Department of Occupational Medicine, First Medical Faculty, Charles University in Prague and General University Hospital in Prague, Na Bojišti 1,120 00 Prague, Czech Republic. E-mail: daniela.pelclova @ If1.cuni.cz

http://dx.doi.org/10.21101/cejph.a4640

\section{INTRODUCTION}

In Czechoslovakia, lead was banned for interior use by Act No. 137/1924 Coll. (1). This legislation was crucial for preventing lead poisonings in painters and varnishers, and also included the description of the symptoms of lead intoxication and instructions for preventive periodic examinations in the workers. Therefore, lead from paint does not constitute a common public health problem in the Czech Republic. Nowadays, the symptoms, sources, and treatment of lead poisonings are less well known, and their diagnostics may pose a problem. Lead compounds have been used in lead paints for transparent and white, yellow, orange, red, brown, blue, and green coloured glazes. Lead is still commonly used in lead-acid batteries, bullets and shots, fusible alloys, as a radiation shield in medical settings, and in many other applications. On the other hand, in order to decrease toxic pollution and environmental contamination that affected humans, many countries, including the Czech Republic no longer use tetraethyl lead as an additive in leaded fuels to reduce engine knocking.

\section{Unexpected Lead Poisoning in a Family}

In December 2013, a 30-year-old man used a grinding machine to remove white paint from the timber ceiling (about $16 \mathrm{~m}^{2}$ ) of the children's room in a house where the family had moved in 2010. The house was built in the late 1940s; the ceiling was probably painted white in the 1950s. The reconstruction of the building was done in several steps; the removal of the paint was finally finished on December 31.
In the middle of January 2014 the man began to feel exhausted and experienced epigastric pains. In the middle of April he visited his general practitioner and had the first examination. Due to the increase in the abdominal colic he was examined at a surgery department and an X-ray and ultrasonography (USG) of the abdomen were performed. Anaemia with hemoglobin levels of $92 \mathrm{~g} / \mathrm{l}$ was found, and a colonoscopy was planned. However, due to a severe colicky pain one week later, he had another X-ray, USG of the abdomen, and gastroscopy, all with physiological findings. The colonoscopy did not find the cause of the pain or any source of bleeding. At the end of May 2014 a sternal puncture was performed, which led to the suspicion of lead poisoning due to impaired hemoglobinization and basophilic stippling associated with normoblast erythropoiesis. His blood lead levels and other markers of lead intoxication are shown in Table 1. It twofold exceeded the Czech occupational limit for workers of $400 \mu \mathrm{g} / 1$ according to the Decree No. 181/2015 Coll. (2).

Accordingly, the voltammetric analysis of the paint dust that the patient brought to the hospital confirmed that it was the source of his poisoning, as $530 \mathrm{mg}$ of lead/ $\mathrm{kg}$ were found in an acidic solution of the sample by atomic spectrometry.

After the lead poisoning was proven by the laboratory tests, the young man was admitted to hospital for the antidotal treatment in July, 2014. On admission, his blood lead (534 $\mu \mathrm{g} / \mathrm{l})$ still exceeded the limit for workers. His blood count was in the normal range, but his 5-aminolaevulinic acid dehydratase (ALA-D) in erythrocytes was $5.4 \mu \mathrm{M} / 1$ (which corresponded to only $9 \%$ of the reference value). A treatment with dimercaptosuccinic acid (DMSA, succimer) at a dose of $30 \mathrm{mg} / \mathrm{kg}$ daily was started and the 
Table 1. Blood lead and other biological exposure tests/markers of exposure to lead in the father in May 2014 (before antidotal treatment)

\begin{tabular}{|l|c|c|c|c|}
\hline Units & $\begin{array}{c}\text { Blood lead } \\
\mu \mathrm{g} / \mathrm{l}\end{array}$ & $\begin{array}{c}\text { Porphyrins } \\
\mu \mathrm{g} / \mathrm{l}\end{array}$ & $\begin{array}{c}\text { Coproporphyrins } \\
\mu \mathrm{mol} / \mathrm{l}\end{array}$ & $\begin{array}{c}\text { 5-ALA } \\
\boldsymbol{\mu g} / \mathrm{l}\end{array}$ \\
\hline Level measured & 800 & 4,223 & 3,080 & 834 \\
\hline Reference value/upper limit & 80 & 144 & 0.28 & 20 \\
\hline
\end{tabular}

5-ALA = 5-aminolaevulinic acid

Table 2. Blood lead $(\mu \mathrm{g} / \mathrm{l})$ in the daughters before and after antidotal treatment given in October 2014 and March 2015

\begin{tabular}{|l|c|c|c|c|c|}
\hline & September 2014 & October 2014 & December 2014 & February 2015 & March 2015 \\
\hline Daughter 5-year-old & 356 & 69 & 297 & 286 & 72 \\
\hline Daughter 2.5-year-old & 240 & 78 & 195 & 180 & 48 \\
\hline
\end{tabular}

Upper limit of the reference value for children is $45 \mu \mathrm{g} / \mathrm{l}$.

patient excreted a maximum of $1.94 \mathrm{mg} / 24$ hours of lead. Within first two days his blood lead lowered to $283 \mu \mathrm{g} / \mathrm{l}$. The outpatient succimer treatment was then continued for another three days. He then recovered uneventfully ( 4 weeks later his ALA and porphyrins were in the normal range and $\mathrm{Pb}$ in urine was $0.012 \mathrm{mg} / 24 \mathrm{~h}$ ).

Additionally, due to the suspicion of lead intoxication the two daughters of the patient were examined in summer 2014. Their blood count, porphyrins and ALA were in the normal range. However, their blood lead exceeded reference values for children, as shown in Table 2. Both girls were treated with succimer at levels of $30 \mathrm{mg} / \mathrm{kg}$ daily for five days in the hospital and then at home with $20 \mathrm{mg} / \mathrm{kg}$ daily during following two weeks. The blood lead levels after DMSA therapy in the older and the younger girls lowered nevertheless the girls deserved second antidotal treatment, as shown in Table 2.

Because the whole family was exposed to the dust during the removal of the paint and subsequent cleaning, the wife's blood lead was measured and a concentration of $235 \mu \mathrm{g} / 1$ was found (the reference level for women is $65 \mu \mathrm{g} / \mathrm{l}$ ) (3); her blood level spontaneously dropped to $89 \mu \mathrm{g} / \mathrm{l}$ in May 2015. Interestingly, the 13-year-old dog of the family developed epileptiform seizures, colic and incontinency, was very thirsty, and died suddenly in March 2014. Its blood lead was not examined.

\section{DISCUSSION}

In the Czech Republic, both occupational and environmental lead poisonings are now rare, unlike in several non-European countries, where the old lead-based paint and lead in the soil from historical use of leaded gasoline continue to be the most important sources of lead exposure for children $(4,5)$.

The first symptoms of lead intoxications after subacute exposure through either inhalation and/or ingestion are usually gastrointestinal. Cramping, colicky abdominal pain, and constipation often present within few days. Abdominal pain may be severe, suggesting appendicitis, biliary colic, kidney colic, or a gastroduodenal ulcer. Headaches, anorexia, fatigue, and insomnia are common complaints. Pallor due to anaemia is common, and a bluish "lead-line" on gums is seen in some rare cases. In the blood count, normocytic normochromic anaemia with reticulocytosis and basophilic stippling is typically found.
Chronic exposure may lead to chronic nephropathy and hypertension. Peripheral neuropathy and arthropathy are seen in rare cases. Lead may also affect spermatogenesis. At very high blood levels, lead encephalopathy with headaches, confusion, drowsiness, coma, and seizures secondary to cerebral edema may occur. This is more common in children and is likely to occur at blood lead concentrations $\geq 1,000 \mu \mathrm{g} / \mathrm{l}$; i.e. $4.8 \mu \mathrm{mol} / 1$ (6). Physiologic differences between children and adults account for much of the increased susceptibility of small children to the deleterious effects of lead; whereas in adults $94 \%$ of lead body burden is stored in bones and teeth, this proportion is only $70 \%$ in children. Additionally, the continuous growth of young children leads to constant bone remodeling for skeletal development. This contributes to a state in which lead stored in bones is continually released back into the blood compartment, a process that has been described as "endogenous contamination" (7), which was also seen in the two daughters.

Remediation efforts typically result in a slow reduction of blood lead levels in exposed children, and the time required in children who were not treated with chelation drugs is about two years $(8,9)$. There is little correlation between the blood lead level and total body lead burden, since blood concentration reflects only recent exposure. Blood levels between 200 and $440 \mu \mathrm{g} / \mathrm{l}$ (0.96 to $2.16 \mu \mathrm{mol} / \mathrm{l})$ may indicate the need for admission to a hospital with chelation therapy, which should occur in parallel with identifying and removing significant sources of lead exposure (10).

In the Czech Republic, the Human Biomonitoring Project (CZ-HBM), launched in 1994 as an integral part of the nationwide Environmental Health Monitoring System (EHMS), observed a significant downward time trend for the blood lead levels in adults and children. Based on the results of the biomonitoring, the reference value for the male, female and children's population in the period 2005-2009 was set at 80, 55 and $45 \mu \mathrm{g} / 1$, respectively (11).

Unlike in Asia, the European cities showed only minor differences in blood lead levels, which were in the range of 14-20 $\mu \mathrm{g} / 1(12,13)$.

Everywhere in the world, unexpected non-occupational environmental poisonings still occur both in the adults and children, and almost as a rule, the way to the diagnosis is not simple. One of the reasons for the difficulty is that lead is a cumulative poison and first symptoms appear without any unusual event in the life of the subjects and after several weeks to months of rather small, continuous exposure. The intoxication may lead to futile 
and invasive diagnostic procedures and the poisoning of several members of a family is not an exception (14-16). The patients are helped frequently following an inquiry to the Toxicological Information Centre*, similarly as in other rare poisonings with metals $(17,18)$. The number of calls concerning lead-related symptoms in the last 3 years is relatively stable and concerns 8-16 calls/year. The sources of poisonings most often involve ceramics with lead containing glaze or ingestion of lead shots. Additionally, lead may be found in a number of consumer products, children's toys, jewelry, cosmetics, candy, chocolate, and ethnic and folk remedies imported from non-European countries (19). Dietary supplements, foods, and packaging can contain high lead levels. Several spices, especially Hungarian paprika, have been contaminated and caused epidemic poisonings (20). Sadly, in 2007 even painting easels and toys for children, coated with high-lead paints, were imported from China to the United States and Europe (21).

There are still reasons to use lead. Lead-based pigments are marginally cheaper for some products, they are easy to produce, and are widely available. Lead compounds are typically added to oil-based enamel paints as pigments, or to improve opacity and durability (22).

In many countries outside Europe, the elimination of lead paint from the environment is far from over, and some commercial products from these countries may be imported (23).

\section{CONCLUSIONS}

Over the past century, lead blood levels in the Central European population and many other countries fell. The number of occupational (24) and environmental intoxications dropped significantly (4), which also decreased the awareness of the risks and the symptoms of lead poisoning.

The awareness of the problem and the knowledge of the symptoms of intoxication, such as anaemia and abdominal pain, and diagnostics tools are some of the most crucial points.

\section{Acknowledgements}

Supported by the Project of the Charles University in Prague P25/1LF/2 and $\mathrm{P} 28 / 1 \mathrm{LF} / 6$. The authors appreciate the language corrections done by Kayleigh Kavanagh, BS.

\section{Conflicts of Interests}

None declared

\section{REFERENCES}

1. Act No. 137/1924 Coll. concerning the safety rules for workers employed in the crafts of painters, varnishers and decorators. Sbírka zákonů a nařízení [Internet]. 1924 Jun 28 [cited 2015 Nov 15];Pt 70:845-8. Available from: http://ftp.aspi.cz/opispdf/1924/070-1924.pdf. (In Czech.)

2. 2. Decree No. $181 / 2015$ Coll. amending the Decree No. 432/2003 Coll., enacting the conditions for job categories, limit values of biological exposure tests, conditions for sampling of biological materials for biological exposure tests and requirements of reports on work with asbestos and biological agents, as amended by Decree No. 107/2013 Coll. Sbírka zákonů ČR. 2015 Jul 24;Pt 74:2214-6.
3. Čejchanová M, Wranová K, Spěváčková V, Krsková A, Šmíd J, Černá M. Human bio-monitoring study - toxic elements in blood of women. Cent Eur J Public Health. 2012 Jun;20(2):139-43.

4. Jarolímek J, Urban P. Twenty year development of occupational diseases in the Czech Republic: medical and geographical aspects. Cent Eur J Public Health. 2014 Dec;22(4):251-6.

5. Pawlas N, Strömberg U, Carlberg B, Cerna M, Harari F, Harari R, et al. Cadmium, mercury and lead in the blood of urban women in Croatia, the Czech Republic, Poland, Slovakia, Slovenia, Sweden, China, Ecuador and Morocco. Int J Occup Med Environ Health. 2013 Mar;26(1):58-72.

6. Toxbase [Internet]. UK National Poisons Information Service; c19832016 [cited 2015 Oct 30]. Available from: http://www.toxbase.org/ Poisons-Index-A-Z/L-Products/Lead/.

7. Gulson BL, Mizon KJ, Korsch MJ, Howarth D, Phillips A, Hall J. Impact on blood lead in children and adults following relocation from their source of exposure and contribution of skeletal tissue to blood lead. Bull Environ Contam Toxicol. 1996 Apr;56(4):543-50.

8. Roberts JR, Reigart JR, Ebeling M, Hulsey TC. Time required for blood lead levels to decline in nonchelated children. J Toxicol Clin Toxicol. 2001;39(2):153-60.

9. Kennedy C, Lordo R, Sucosky MS, Boehm R, Brown MJ. Primary prevention of lead poisoning in children: a cross-sectional study to evaluate state specific lead-based paint risk reduction laws in preventing lead poisoning in children. Environ Health. 2014 Nov 7;13:93.

10. TOXINZ Poisons Information [Internet]. Dunedin: University of Otago, National Poisons Centre; c2016 [cited 2015 Nov 5]. Available from: http:// www.toxinz.com/.

11. Černá M, Krsková A, Čejchanová M, Spěváčková V. Human biomonitoring in the Czech Republic: an overview. Int J Hyg Environ Health. 2012 Feb;215(2):109-19.

12. Hrubá F, Strömberg U, Černá M, Chen C, Harari F, Harari R, et al. Blood cadmium, mercury, and lead in children: an international comparison of cities in six European countries, and China, Ecuador, and Morocco. Environ Int. 2012 May;41:29-34.

13. Brázdová ZD, Pomerleau J, Fiala J, Vorlová L, Müllerová D. Heavy metals in hair samples: a pilot study of anaemic children in Kazakhstan, Kyrgyzstan and Uzbekistan. Cent Eur J Public Health. 2014 Dec;22(4):273-6.

14. Pelclová D, Urban P, Lukáš E, Ridzoň P, Šenholdová Z. Health effects of metals - case studies - metal intoxications with neurotoxicological consequences. In: Vojtisek M, Prakash R, editors. Metals and neurotoxicity. Jalgaon: Society for Science and Environment; 2009. p. 93-103.

15. Vlček K, Šenholdová Z, Pelclová D, Žák J, Surovcová H. Severe lead intoxication after ingestion of lead shots. Cas Lek Ces. 2005;144(2):282-4. (In Czech.)

16. Hoffmanová I, Kačírková P, Kučerová I, Ševčík R, Sánchez D. Lead poisoning - a surprising cause of obstipation, abdominal pain and anemia. Vnitr Lek. 2016;62(2):157-63. (In Czech.)

17. Pelclová D, Lukás E, Urban P, Preiss J, Rysavá R, Lebenhart P, et al. Mercury intoxication from skin ointment containing mercuric ammonium chloride. Int Arch Occup Environ Health. 2002 Oct;75 Suppl:S54-9.

18. Pelclová D, Urban P, Ridzon P, Senholdová Z, Lukás E, Diblík P, et al. Two-year follow-up of two patients after severe thallium intoxication. Hum Exp Toxicol. 2009 May;28(5):263-72.

19. Ko RJ. Adulterants in Asian patent medicines. N Engl J Med. 1998 Sep 17;339(12):847.

20. Kákosy T, Hudák A, Náray M. Lead intoxication epidemic caused by ingestion of contaminated ground paprika. J Toxicol Clin Toxicol. 1996;34(5):507-11.

21. Levin R, Brown MJ, Kashtock ME, Jacobs DE, Whelan EA, Rodman J, et al. Lead exposures in U.S. Children, 2008: implications for prevention. Environ Health Perspect. 2008 Oct;116(10):1285-93.

22. Amitai Y, Graef JW, Brown MJ, Gerstle RS, Kahn N, Cochrane PE. Hazards of 'deleading' homes of children with lead poisoning. Am J Dis Child. 1987 Jul;141(7):758-60.

23. Jakab Z, Tsouros AD. Health 2020 - achieving health and development in today's Europe. Cent Eur J Public Health. 2014 Jun;22(2):133-8.

24. Pelclová D, Pícková J, Patzelová V. Chromosomal aberrations, hormone levels and oxidative phenotype (P450 2D6) in low occupational lead exposure. Central Eur J Occup Environ Med. 1997;3(4):314-22.

*http://www.tis-cz.cz 